\title{
POTENSI PEMBELAJARAN SAINTIFIK BERNUANSA ETNOSAINS UNTUK MEMBERDAYAKAN KEMAMPUAN BERPIKIR KRITIS SISWA
}

\author{
Oleh: Eni Widayanti \\ (Guru SMP N 3 Surakarta) \\ Email: eniwida10@yahoo.co.id
}

\begin{abstract}
Abstrak
Tujuan penulisan ini adalah mengetahui pembelajaran saintifik bernuansa etnosains dapat memberdayakan kemampuan berpikir kritis siswa kelas VII SMP Negeri 3 Surakarta. Metode penelitian yang digunakan adalah penelitian tindakan kelas. Hasil analisis membuktikan bahwa Sebagian besar siswa atau lebih dari 50 \% siswa belum memenuhi indikator kemampuan berpikir kritis berdasarkan observasi yang telah dilakukan sehingga kemampuan berpikir kritis siswa di SMP Negeri 3 Surakarta masih rendah. Solusi permasalahan yang terjadi dapat diselesaikan dengan menerapkan pembelajaran saintifik bernuansa etnosains untuk memberdayakan kemampuan berpikir kritis. Sehingga meningkatkan daya kemampuan berpikir kritis siswa.
\end{abstract}

Kata Kunci: Pembelajaran Saintifik, Etnosains, Kemampuan Berpikir Kritis

\section{THE POTENTIAL OF LEARNING SCIENCES OF NATIONAL HOSPITALITY ASSOCIATION TO EMPOWER THINKING ABILITY STUDENT CRITICAL}

\begin{abstract}
The purpose of this writing is to know the ethnographic nuanced scientific learning can empower critical thinking skills of class VII students of SMP Negeri 3 Surakarta. The research method used was classroom action research. The results of the analysis prove that the majority of students or more than $50 \%$ of students have not met the indicators of critical thinking skills based on observations that have been made so that the critical thinking skills of students in SMP Negeri 3 Surakarta is still low. The solution to the problems that occur can be solved by applying scientific learning nuanced ethnoscience to empower critical thinking skills. Thus increasing the ability of students' critical thinking skills
\end{abstract}

Keywords: Scientific Learning, Ethnoscience, Critical Thinking Ability 
Potensi Pembelajaran Saintifik.... (Eni Widayanti)

\section{A. PENDAHULUAN}

Keberhasilan dalam bidang pendidikan tentunya tak lepas dari keberhasilan dalam mencapai tujuan pembelajaran di sekolah. Salah satu faktor yang berpengaruh dalam mencapai tujuan pembelajaran adalah proses kegiatan belajar mengajar. Tujuan pembelajaran tersebut berkaitan dengan pencapaian prestasi siswa. Prestasi siswa ini tidak hanya dilihat pada aspek kognitifnya saja, namun dilihat juga dari aspek afektif dan psikomotornya. Oleh karena itu, sangatlah penting untuk melaksanakan proses kegiatan belajar mengajar dengan baik dalam rangka mencapai tujuan pembelajaran.

Proses kegiatan belajar mengajar tidak hanya sekedar guru menjelaskan materi pelajaran kepada siswa. Pastinya proses pembelajaran yang efektif, interaktif, dan menarik tercipta ketika siswa memiliki rasa ingin tahu dan aktif dalam pembelajaran. Pada proses pembelajaran terdapat suatu input, proses, dan output. Input dapat berupa guru, siswa, bahan ajar, dan media pembelajaran. Proses dapat berupa metode, model, dan strategi pembelajaran yang berkaitan dengan langkah-langkah dalam melaksanakan proses kegiatan belajar mengajar. Sedangkan output adalah hasil belajar siswa.

Melalui pembelajaran saintifik siswa dipicu untuk bertanya setelah mereka mengamati suatu fenomena. Pertanyaan ini menunjukkan adanya rasa ingin tahu dari siswa dan kritisnya siswa terhadap fenomena yang terjadi. Kurikulum 2013 ini menerapkan suatu pembelajaran yang dapat dilakukan di kelas yaitu pembelajaran saintifik melalui kegiatan pengamatan (observasi), mengajukan pertanyaan, mengumpulkan data, mengasosiasi atau menalar, dan mengkomunikasikan (Sani, 2014). Melalui rangkaian kegiatan pembelajaran saintifik tersebut diharapkan mampu memberikan pengalaman langsung pada siswa untuk mengumpulkan informasi sehingga mereka mampu membangun pengetahuannya sendiri terhadap materi yang dipelajari. Selain itu, siswa diharapkan mampu menyampaikan penemuannya pada orang lain dan memberikan argumennya. Apabila siswa melalui semua kegiatan pembelajaran saintifik yang memberikan pengalaman langsung pada siswa maka memungkinkan siswa untuk belajar ketrampilan baru, sikap baru, atau bahkan 
cara berpikir baru. Selain itu, pembelajaran akan bermakna ketika siswa berperan serta dalam melakukan kegiatan belajar mengajar (Hosnan, 2014).

Suatu pembelajaran akan lebih bermakna dan bermanfaat jika siswa tahu penerapan materi yang dipelajari dalam kehidupan sehari-hari sehingga kualitas pembelajaran dapat meningkat. Salah satu cara yang dapat dilakukan agar pembelajaran lebih bermakna dan bermanfaat dengan cara memperkenalkan kepada siswa mengenai sains asli yang ada pada suatu daerah atau bangsa yang disebut dengan etnosains. Sains asli yang ada pada suatu daerah atau bangsa nantinya akan dihubungkan dengan sains ilmiah yang dipelajari siswa di sekolah. Stanley dan Brickhouse menyarankan agar pembelajaran sains di sekolah menyelaraskan antara sains Barat (sains modern) dengan sains asli (sains tradisional) dengan menggunakan pendekatan lintas budaya (cross-culture).

Menurut Barnhardt (n.d.), prinsip dalam menerapkan pembelajaran berbasis budaya lokal adalah "think globally, act locally." Ini mengandung makna bahwa tujuan dari pembelajaran berbasis budaya lokal adalah mencapai keterampilan berpikir secara global, yaitu dapat memecahkan masalah-masalah di sekitar dan masalah-masalah global. Namun, keterampilan berpikir ini dicapai melalui tindakan-tindakan lokal. Hal ini dapat dicapai salah satunya dengan mengaitkan pembelajaran sains dengan budaya lokal (Sudarmin, 2014).

Glaser mendefinisikan berpikir kritis sebagai suatu sikap mau berpikir secara mendalam tentang masalah-masalah dan hal-hal yang berada dalam jangkauan pengalaman seseorang. Sedangkan menurut Paul berpikir kritis merupakan mode berpikir mengenai hal, substansi, atau masalah apa saja dimana si pemikir meningkatkan kualitas pemikirannya dengan menangani secara terampil struktur-struktur yang melekat pada pemikiran dan menerapkan standarstandar intelektual padanya (Fisher, 2009). Berpikir kritis merujuk pada kemampuan melontarkan dan menjawab pertanyaan kritis pada saat yang tepat serta mau untuk menggunakan pertanyaan kritis tersebut secara aktif (Browne dan Keeley, 2015). Berdasarkan beberapa pengertian yang ada, dapat disimpulkan bahwa berpikir kritis merupakan kemauan dan kemampuan berpikir secara mendalam dengan cara melontarkan atau menjawab pertanyaan kritis secara aktif 
mengenai hal atau masalah apa saja dan menggunakan pertanyaan tersebut untuk melakukan kegiatan pembelajaran secara aktif untuk meningkatkan kualitas pemikirannya.

Ketika siswa memiliki kemampuan berpikir kritis setidaknya siswa akan memiliki ketrampilan dalam mengidentifikasi elemen kasus, mengevaluasi asumsi, mengklarifikasi dan mengintepretasi pertanyaan dan gagasan, menganalisis dan menghasilkan penjelasan serta argumen (Fisher, 2009). Berpikir kritis diperlukan dalam suatu upaya penyelidikan dalam rangka membangun pengetahuan. Melalui upaya tersebut, dengan berpikir kritis siswa akan dengan sendirinya berusaha untuk meningkatkan pemikirannya dalam mempelajari suatu konsep. Tentunya proses berpikir kritis ini juga sangat dibutuhkan siswa untuk mempelajari materi-materi pelajaran sehingga pada akhirnya diharapkan siswa dapat mempelajari secara mendalam tentang semua hal yang ingin diketahuinya dan dapat mencapai prestasi yang baik.

Setelah dilakukan observasi di SMP Negeri 3 Surakarta diperoleh hasil bahwa kegiatan belajar mengajar di tiga sekolah tersebut belum mampu membangkitkan kemampuan berpikir kritis siswa. Hal tersebut terlihat dengan pasifnya siswa selama mengikuti proses pembelajaran. Selain itu, pada saat guru menjelaskan materi pelajaran dan melakukan tanya jawab interaktif hanya sekitar 1-2 anak saja yang mau menjawab pertanyaan-pertanyaan dari guru. Saat guru memberikan kesempatan pada siswa untuk bertanya tidak ada siswa yang terlihat menanyakan sesuatu.

Selama proses pembelajaran guru di SMP Negeri 3 Surakarta berusaha untuk memberikan gambaran materi pelajaran dengan menggunakan bandul sederhana dan memberikan pertanyaan-pertanyaan dengan menggunakan bandul tersebut, namun sebagian besar siswa hanya diam saja dan tidak merespon pertanyaan guru. Tidak ada usaha dan kemauan dari siswa untuk menjawab dan memikirkan apa yang ditanyakan oleh guru. Terlihat sekali siswa tidak memiliki antusias dalam mengikuti kegiatan belajar mengajar. Saat siswa diberi tugas untuk dikerjakan dirumah juga masih ada sekitar 3-5 anak yang tidak mengerjakan tugas tersebut, 2-4 anak tidak membawa tugas tersebut dan beralasan bahwa tugas 
tersebut tertinggal dirumah. Kemampuan berpikir kritis siswa masih tergolong rendah juga dapat disebabkan karena proses pembelajaran yang kurang mampu untuk membangkitkan dan mengasah kemampuan berpikir kritis siswa. Tidak ada pertanyaan-pertanyaan, hal, atau masalah kritis yang disajikan dalam pembelajaran yang dapat memicu siswa untuk berpikir kritis.

Berdasarkan uraian-uraian tersebut maka dapat diterapkan model pembelajaran saintifik bernuansa etnosains untuk memberdayakan kemampuan berpikir kritis siswa. Berdasarkan masalah yang akan diteliti dalam penelitian ini, maka dapat dirumuskan rumusan masalahnya yaitu apakah pembelajaran saintifik bernuansa etnosains dapat memberdayakan kemampuan berpikir kritis siswa kelas VII SMP Negeri 3 Surakarta.

\section{B. METODOLOGI PENELITIAN}

Metode penelitian pada penelitian ini adalah metode Penelitian Tindakan Kelas (PTK) yang berusaha mengkaji dan merefleksi penggunaan model pembelajaran matematika berbasis masalah dengan tujuan meningkatkan kemampuan pemecahan masalah matematis siswa mengenai soal cerita pecahan. PTK ini dilakukan dengan tujuan memperbaiki mutu praktik pembelajaran di kelas. Kusnandar (2010, hlm. 51) menjelaskan bahwa terdapat beberapa alasan PTK menjadi salah satu pendekatan dalam meningkatkan atau memperbaiki mutu pembelajaran adalah: 1) merupakan pendekatan pemecahan masalah yang bukan sekedar trial and error; 2) menggarap masalah-masalah faktual yang dihadapi dalam pembelajaran; 3) tidak perlu meninggalkan tugas utamanya, yakni mengajar; 4) dosen sebagai peneliti; 5) mengembangkan iklim akademik dan profesionalisme dosen; 6) dapat segera dilaksanakan pada saat muncul kebutuhan; 7) dilaksanakan dengan tujuan perbaikan; 8) murah biayanya; 9) disain lentur atau fleksibel; 10) analisis data seketika dan tidak rumit; dan 11) manfaat jelas dan langsung. 
Potensi Pembelajaran Saintifik.... (Eni Widayanti)

\section{HASIL PENELITIAN DAN PEMBAHASAN}

Ketika siswa memiliki kemampuan berpikir kritis setidaknya siswa akan memiliki ketrampilan dalam mengidentifikasi elemen kasus, mengevaluasi asumsi, mengklarifikasi dan mengintepretasi pertanyaan dan gagasan, menganalisis dan menghasilkan penjelasan serta argumen (Fisher, 2009).

Berpikir kritis diperlukan dalam suatu upaya penyelidikan dalam rangka membangun pengetahuan. Melalui upaya tersebut, dengan berpikir kritis siswa akan dengan sendirinya berusaha untuk meningkatkan pemikirannya dalam mempelajari suatu konsep. Tentunya proses berpikir kritis ini juga sangat dibutuhkan siswa untuk mempelajari materi-materi pelajaran sehingga pada akhirnya diharapkan siswa dapat mempelajari secara mendalam tentang semua hal yang ingin diketahuinya dan dapat mencapai prestasi yang baik.

Sebagian besar siswa mampu menjawab soal yang diberikan guru. Namun siswa cenderung pasif di tempat duduknya. Ketika guru menanyakan suatu hal yang berkaitan dengan suatu fenomena, siswa cenderung diam. Selain itu siswa juga hanya menerima penjelasan dari guru tanpa ada rasa ingin tahu lebih lanjut terhadap yang disampaikan guru. Gejala-gejala tersebut erat kaitannya dengan kemampuan berpikir tingkat tinggi, khususnya kemampuan berpikir kritis.

Penulis disini memilih indikator yang dikemukakan oleh Angelo. Penulis mempertimbangkan bahwa indikatornya tidak terlalu banyak tetapi sudah mewakili untuk mengamati kemampuan berpikir kritis siswa.

Tabel 2

Indikator Masalah Kemampuan Berpikir Kritis

\begin{tabular}{|c|c|c|c|}
\hline $\begin{array}{c}\text { Potensi } \\
\text { Masalah }\end{array}$ & Indikator & Masalah & Argumen \\
\hline $\begin{array}{l}\text { Kemampu- } \\
\text { an Berpikir } \\
\text { Kritis }\end{array}$ & $\begin{array}{l}\text { 1. Mengenal } \\
\text { masalah. }\end{array}$ & 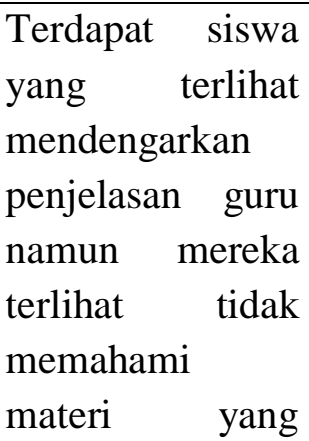 & $\begin{array}{l}\text { Setiawan dalam Santoso } \\
\text { (2010) bahwa pembelajaran } \\
\text { yang meminta siswa untuk } \\
\text { memahami atau merumuskan } \\
\text { masalah, tujuan dan hipotesis, } \\
\text { serta menganalisis untuk } \\
\text { menjawab permasalahan yang } \\
\text { telah dirumuskan dapat }\end{array}$ \\
\hline
\end{tabular}




\begin{tabular}{|c|c|c|c|}
\hline $\begin{array}{r}\text { Potensi } \\
\text { Masalah }\end{array}$ & Indikator & Masalah & Argumen \\
\hline & & $\begin{array}{l}\text { dijelaskan guru. } \\
\text { Siswa tidak } \\
\text { berusaha } \\
\text { bertanya dan saat } \\
\text { siswa di beri } \\
\text { pertanyaan tidak } \\
\text { dapat } \\
\text { menjawabnya. }\end{array}$ & $\begin{array}{l}\text { mengembangkan kemampuan } \\
\text { berpikir kritis siswa. Ketika } \\
\text { siswa terlihat diam dan terlihat } \\
\text { tidak memahami materi yang } \\
\text { dijelaskan oleh guru dan tidak } \\
\text { mau bertanya dapat dikatakan } \\
\text { bahwa siswa tidak dapat } \\
\text { mengenal masalah }\end{array}$ \\
\hline & $\begin{array}{l}\text { 2. Menemu- } \\
\text { kan cara- } \\
\text { cara } \\
\text { untuk } \\
\text { mengatasi } \\
\text { masalah. }\end{array}$ & $\begin{array}{l}\text { Tidak ada siswa } \\
\text { yang bertanya } \\
\text { ketika } \\
\text { mengalami } \\
\text { kesulitan dan } \\
\text { guru sudah } \\
\text { memberi } \\
\text { kesempatan } \\
\text { untuk bertanya. }\end{array}$ & $\begin{array}{l}\text { Siswa yang berpikir kritis akan } \\
\text { menanyakan setiap fenomena } \\
\text { yang tidak dapat mereka } \\
\text { mengerti secara cepat. Hal Ini } \\
\text { sesuai dengan pendapat Glaser } \\
\text { (1941) mendefinisikan berpikir } \\
\text { kritis sebagai suatu sikap mau } \\
\text { berpikir secara mendalam } \\
\text { tentang masalah-masalah dan } \\
\text { hal-hal yang berada dalam } \\
\text { jangkauan seseorang. }\end{array}$ \\
\hline & $\begin{array}{l}\text { 3. Mengum- } \\
\text { pulkan dan } \\
\text { menyusun } \\
\text { informasi. }\end{array}$ & $\begin{array}{l}\text { Siswa hanya } \\
\text { menggunakan } \\
\text { bahan ajar dari } \\
\text { LKS. }\end{array}$ & $\begin{array}{lrr}\text { Siswa yang } & \text { memiliki } \\
\text { kemampuan berpikir } & \text { kritis } \\
\text { yang tinggi } & \text { akan } \\
\text { mengumpulkan dan menyusun } \\
\text { informasi dari beberapa } \\
\text { sumber. }\end{array}$ \\
\hline & $\begin{array}{l}\text { 4. Mengenal } \\
\text { asumsi- } \\
\text { asumsi } \\
\text { dan nilai- } \\
\text { nilai yang } \\
\text { tidak } \\
\text { dinyatak- } \\
\text { an. }\end{array}$ & $\begin{array}{l}\text { Sebagian besar } \\
\text { siswa belum bisa } \\
\text { mengungkapkan } \\
\text { alasan kenapa } \\
\text { memilih jawaban } \\
\text { yang mereka } \\
\text { pilih. }\end{array}$ & $\begin{array}{lrr}\text { Mereka } & \text { tidak } & \text { dapat } \\
\text { memberikan asumsi } & \text { dari } \\
\text { sebuah niali yang } & \text { tidak } \\
\text { dinyatakan secara } & \text { terbuka } \\
\text { tentang sebuah } & \text { konsep } \\
\text { sehingga akhirnya } & \text { mereka } \\
\text { tidak dapat memberikan alasan } \\
\text { memilih suatu jawaban. }\end{array}$ \\
\hline
\end{tabular}




\begin{tabular}{|c|c|c|c|}
\hline $\begin{array}{c}\text { Potensi } \\
\text { Masalah }\end{array}$ & Indikator & Masalah & Argumen \\
\hline & $\begin{array}{l}\text { 5. Memaha- } \\
\text { mi dan } \\
\text { mengguna } \\
\text { kan } \\
\text { bahasa } \\
\text { yang } \\
\text { tepat, } \\
\text { jelas dan } \\
\text { khas. }\end{array}$ & $\begin{array}{lr}\text { Sebagian } & \text { siswa } \\
\text { bersikap pasif } \\
\text { selama proses } \\
\text { belajar mengajar } \\
\text { dan hanya } \\
\text { beberapa siswa } \\
\text { saja yang mau } \\
\text { menjawab } \\
\text { pertanyaan dari } \\
\text { guru. }\end{array}$ & $\begin{array}{l}\text { Siswa bersikap pasif dapat juga } \\
\text { mengindikasikan bahwa siswa } \\
\text { belum dapat } \\
\text { mengkomunikasikan apa yang } \\
\text { siswa pikirkan. }\end{array}$ \\
\hline & $\begin{array}{l}\text { 6. Mengana- } \\
\text { lisis data. }\end{array}$ & $\begin{array}{l}\text { Siswa tidak } \\
\text { mampu } \\
\text { menganalisis } \\
\text { suatu } \\
\text { permasalahan } \\
\text { terkait dengan } \\
\text { materi yang } \\
\text { dihadapkan oleh } \\
\text { guru. }\end{array}$ & $\begin{array}{l}\text { Ketika siswa tidak mampu } \\
\text { menganalisis suatu } \\
\text { permasalahan dapat dikatakan } \\
\text { bahwa siswa belum mampu } \\
\text { menganalisis data. Menurut } \\
\text { Sudijono (2009:51) "Analisis } \\
\text { (Analysis) adalah kemampuan } \\
\text { seseorang untuk merinci atau } \\
\text { menguraikan suatu bahan atau } \\
\text { keadaan menurut bagian- } \\
\text { bagian yang lebih kecil dan } \\
\text { mampu memahami hubungan } \\
\text { diantara bagian-bagian atau } \\
\text { faktor-faktor yang satu dengan } \\
\text { faktor-faktor lainnya". Siswa } \\
\text { dalam hal ini tidak } \\
\text { menguraikan terlebih dahulu } \\
\text { soal yang ada, bagaimana } \\
\text { satuan masing-masing dari } \\
\text { data. Mereka langsung } \\
\text { memasukkan data-data yang } \\
\text { ada kedalam sebuh persamaan. }\end{array}$ \\
\hline & $\begin{array}{l}\text { 7. Menilai } \\
\text { fakta dan } \\
\text { mengeval } \\
\text { uasi. }\end{array}$ & $\begin{array}{lr}\text { Sebagian } & \text { siswa } \\
\text { bersikap } & \text { pasif } \\
\text { selama } & \text { proses } \\
\text { belajar mengajar. }\end{array}$ & $\begin{array}{l}\text { Siswa yang dapat menilai fakta } \\
\text { dan mengevaluasinya akan } \\
\text { cenderung aktif dalam } \\
\text { pembelajaran. Curto dan Bayer } \\
\text { (2005) menyatakan bahwa }\end{array}$ \\
\hline
\end{tabular}




\begin{tabular}{|c|c|c|c|}
\hline $\begin{array}{c}\text { Potensi } \\
\text { Masalah }\end{array}$ & Indikator & Masalah & Argumen \\
\hline & & & $\begin{array}{l}\text { berpikir kritis } \begin{array}{r}\text { dapat } \\
\text { dikembangkan } \\
\text { memperkaya }\end{array} \\
\text { siswa yang bermakna. }\end{array}$ \\
\hline & $\begin{array}{l}\text { 8. } \\
\text { adangenal } \\
\text { hubungan } \\
\text { logis } \\
\text { antara } \\
\text { masalah }\end{array}$ & $\begin{array}{l}\text { Tidak ada siswa } \\
\text { yang bertanya } \\
\text { terhadap } \\
\text { permasalahan } \\
\text { sehari-hari yang } \\
\text { dijelaskan guru. } \\
\text { Mereka hanya } \\
\text { pasif menerima } \\
\text { segala informasi } \\
\text { yang diberikan } \\
\text { oleh guru. }\end{array}$ & $\begin{array}{l}\text { Siswa yang berpikir kritis akan } \\
\text { menanyakan hal baru yang } \\
\text { diterima. Tidak hanya sekedar } \\
\text { menerima saja. Jika siswa tidak } \\
\text { bertanya apapun saat guru } \\
\text { menjelaskan fenomena yang } \\
\text { dijelaskan guru, maka mereka } \\
\text { kurang mengenal hubungan } \\
\text { logis antar masalah. } \\
\text { Tujuan berpikir kritis yang } \\
\text { dikemukakan oleh Supriya } \\
\text { (2009), adalah untuk menilai } \\
\text { suatu pemikiran, menaksir nilai } \\
\text { bahkan mengevaluasi } \\
\text { pelaksanaan atau praktik dari } \\
\text { suatu pemikiran dan praktik } \\
\text { tersebut. Selain itu, berpikir } \\
\text { kritis meliputi aktivitas } \\
\text { mempertimbangkan } \\
\text { berdasarkan pada pendapat } \\
\text { yang diketahui. }\end{array}$ \\
\hline & 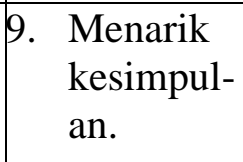 & Belum Teramati & $\begin{array}{l}\text { Guru belum menyajikan suatu } \\
\text { soal yang membutuhkan } \\
\text { penarikan kesimpulan. }\end{array}$ \\
\hline
\end{tabular}

Proses pembelajaran adalah proses yang di dalamnya terdapat kegiatan interaksi antara guru-siswa dan komunikasi timbal balik yang berlangsung dalam situasi edukatif untuk mencapai tujuan belajar (Rustaman, 2001). Dalam proses pembelajaran, guru dan siswa merupakan dua komponen yang tidak bisa dipisahkan. Antara dua komponen tersebut harus terjalin interaksi yang saling menunjang agar hasil belajar siswa dapat tercapai secara optimal. 
Tabel 3

Gejala Masalah Proses Pembelajaran

\begin{tabular}{|c|c|c|}
\hline $\begin{array}{c}\text { Potensi } \\
\text { Masalah }\end{array}$ & Masalah & Argumen \\
\hline \begin{tabular}{|l|} 
Proses \\
Pembelajaran
\end{tabular} & $\begin{array}{l}\text { 1. Kegiatan pembelajaran } \\
\text { masih dilakukan dengan } \\
\text { menggunakan metode } \\
\text { ceramah, pembelajaran } \\
\text { masih berpusat pada } \\
\text { guru. } \\
\text { 2. Siswa belum banyak } \\
\text { diberi ruang untuk } \\
\text { mengembangkan } \\
\text { pemikirannya melalui } \\
\text { kegiatan-kegiatan } \\
\text { ilmiah yang } \\
\text { dilakukannya sendiri } \\
\text { untuk mendapatkan } \\
\text { pengalaman langsung } \\
\text { dalam memperoleh } \\
\text { pengetahuan. } \\
\text { 3. Guru belum } \\
\text { menekankan konsep dan } \\
\text { aplikasi IPA dalam } \\
\text { pembelajaran dan } \\
\text { kehidupan sehari-hari } \\
\text { untuk mewujudkan } \\
\text { pembelajaran yang } \\
\text { efektif. } \\
\text { Dalam proses } \\
\text { pembelajaran siswa } \\
\text { hanya difokuskan pada } \\
\text { latihan-latihan soal. } \\
\text { 5. Belum banyak kegiatan } \\
\text { ilmiah yang dilakukan } \\
\text { oleh siswa guna } \\
\text { mengembangkan } \\
\text { kemampuan berpikir } \\
\text { kritisnya. }\end{array}$ & 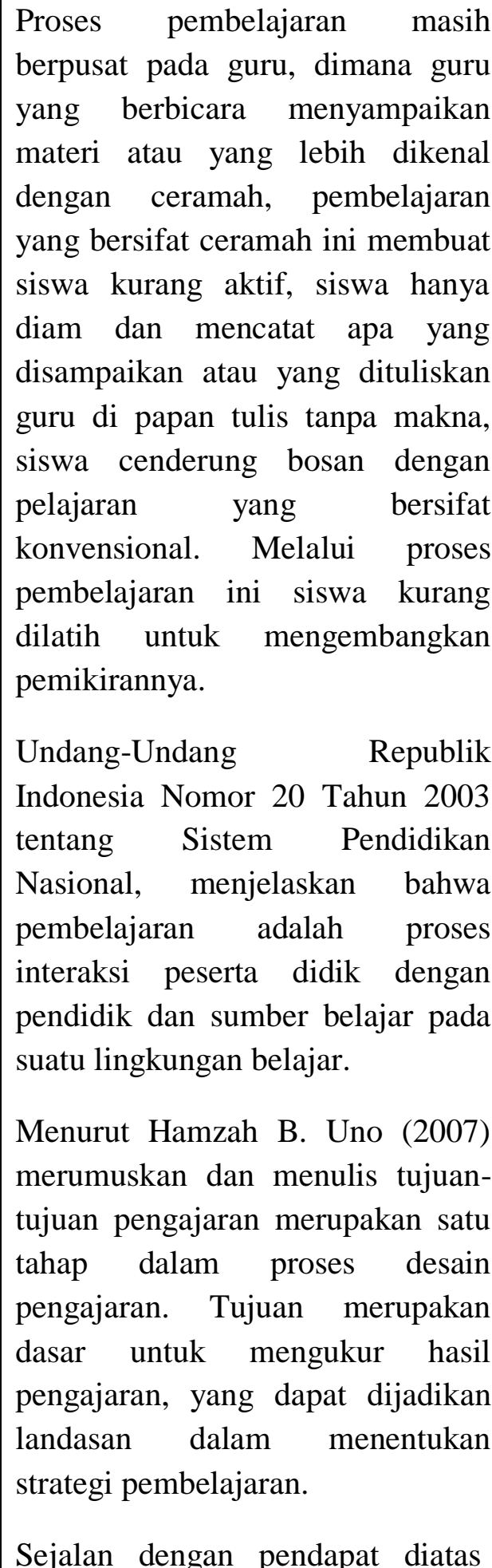 \\
\hline
\end{tabular}




\begin{tabular}{|c|c|l|}
\hline $\begin{array}{c}\text { Potensi } \\
\text { Masalah }\end{array}$ & Masalah & \multicolumn{1}{|c|}{ Argumen } \\
\hline & & $\begin{array}{l}\text { Robert F. Mager dalam Hamzah } \\
\text { B. Uno (2007) menyatakan bahwa } \\
\text { "tujuan pembelajaran adalah } \\
\text { perilaku yang hendak dicapai atau } \\
\text { yang dapat dikerjakan oleh siswa } \\
\text { pada kondisi dan tingkat } \\
\text { kompetensi tertentu". Sedangkan } \\
\text { menurut Hamalik (2005), } \\
\text { menjelaskan bahwa tujuan } \\
\text { pembelajaran adalah suatu } \\
\text { deskripsi menyerupai tingkah laku } \\
\text { yang diharapkan tercapai siswa } \\
\text { setelah berlangsung pembelajaran. }\end{array}$ \\
\hline
\end{tabular}

Sebagian besar siswa atau lebih dari $50 \%$ siswa belum memenuhi indikator kemampuan berpikir kritis berdasarkan observasi yang telah dilakukan sehingga kemampuan berpikir kritis siswa di SMP Negeri 3 Surakarta masih rendah. Kegiatan belajar mengajar masih kurang mampu membangkitkan kemampuan berpikir kritis siswa. Hal tersebut terlihat dengan pasifnya siswa selama mengikuti proses pembelajaran. Selain itu, pada saat guru menjelaskan materi pelajaran dan melakukan tanya jawab interaktif hanya sekitar 1-2 anak saja yang mau menjawab pertanyaan-pertanyaan dari guru.

Hal tersebut dapat disebabkan karena rendahnya kemampuan berpikir kritis siswa atau juga dapat disebabkan karena pertanyaan yang diberikan oleh guru tidak memicu siswa untuk mengembangkan kemampuan berpikir kritisnya. Saat guru memberikan kesempatan pada siswa untuk bertanya tidak ada siswa yang terlihat menanyakan sesuatu. Selama proses pembelajaran guru berusaha untuk memberikan gambaran materi pelajaran dengan menggunakan bandul sederhana dan memberikan pertanyaan-pertanyaan dengan menggunakan bandul tersebut, namun sebagian besar siswa hanya diam saja dan tidak merespon pertanyaan guru. Tidak ada usaha dan kemauan dari siswa untuk menjawab dan memikirkan apa yang ditanyakan oleh guru. Terlihat sekali siswa tidak memiliki antusias dalam 
mengikuti kegiatan belajar mengajar. Saat siswa diberi tugas untuk dikerjakan dirumah juga masih ada sekitar 3-5 anak yang tidak mengerjakan tugas tersebut, 2-4 anak tidak membawa tugas tersebut dan beralasan bahwa tugas tersebut tertinggal di rumah.

\section{PEMBAHASAN}

Kemampuan berpikir kritis siswa masih tergolong rendah juga dapat disebabkan karena proses pembelajaran yang kurang mampu untuk membangkitkan dan mengasah kemampuan berpikir kritis siswa. Tidak ada pertanyaan-pertanyaan, hal, atau masalah kritis yang disajikan dalam pembelajaran yang dapat memicu siswa untuk berpikir kritis. Pembelajaran yang berlangsung juga tidak banyak melibatkan partisipasi dari siswa. Siswa tidak diberi ruang untuk melakukan kegiatan ilmiah yang dapat membantunya untuk mengembangkan kemampuan berpikir kritisnya. Sehingga siswa tidak terbiasa untuk mengembangkan pemikirannya dalam menghadapi suatu permasalahan. Siswa menjadi kurang termotivasi dalam pembelajaran dan akan merasa pelajaran membosankan, sehingga membuat motivasi dan hasil belajar siswa menjadi rendah.

Selama ini pelatihan berpikir kritis disekolah belum berjalan sesuai dengan rencana sehingga siswa belum memiliki kemampuan untuk berpikir kritis. Banyak kendala yang dialami siswa, guru serta sarana prasarana sehingga kemampuan berpikir kritis belum bisa optimal dengan baik sehingga berdampak pada hasil belajar siswa yang rendah pula. Seperti yang sudah dijelaskan di atas bahwa rendahnya kemampuan berpikir kritis yang dimiliki siswa disebabkan karena beberapa hal yaitu guru menggunakan pembelajaran konvensional, yaitu pembelajaran yang hanya berpusat pada guru, yaitu guru menjelaskan materi melalui metode ceramah, sedangkan murid-murid hanya diam dan pasif, pertanyaan siswa terkadang diabaikan, hanya berorientasi terhadap satu jawaban yang benar dan kegiatan di kelas hanya menulis dan mendengarkan. 


\section{SIMPULAN}

Masalah yang terjadi di SMP Negeri 3 Surakarta dalam kegiatan pembelajaran IPA adalah berkaitan dengan masalah pada siswa, guru, dan model pembelajaran yang digunakan.

1. Kemampuan berpikir kritis siswa masih rendah.

2. Fokus utama permasalah yang terjadi adalah kemampuan berpikir kritis siswa yang masih rendah.

3. Solusi permasalahan yang terjadi dapat diselesaikan dengan menerapkan pembelajaran saintifik bernuansa etnosains untuk memberdayakan kemampuan berpikir kritis.

\section{DAFTAR PUSTAKA}

Browne, M.N. dan Keeley, S.M. (2015). Pemikiran Kritis. Terj. Brian Reza Daffi. Jakarta: PT Indeks.

Fisher, A. (2009). Berpikir Kritis. Terj. Benyamin Hadinata. Jakarta: Erlangga.

Hosnan, M. (2014). Pendekatan Saintifik dan Kontekstual dalam Pembelajaran Abad 21. Bogor: Ghalia Indonesia.

Rustaman, N. (2001). Ketrampilan Bertanya dalam Pembelajaran IPA. Dalam Hand Out Bahan Pelatihan Guru-guru IPA SLTP Se Kota Bandung di PPG IPA. Depdiknas.

Sani, A. (2014). Pembelajaran Saintifik untuk Implementasi Kurikulum 2013. Jakarta: Bumi Aksara.

Sudarmin. (2014). Pendidikan Karakter, Etnosaians, dan Kearifan Lokal. Semarang: FMIPA UNNES. 